\title{
An Analysis of Focus on Form Practice in Communicative English Language Teaching Classrooms
}

\author{
M. Maizatulliza \\ Universiti Pendidikan Sultan Idris, Malaysia \\ e-mail:maizatulliza@fbk.upsi.edu.my \\ R. Kiely \\ University of Southampton, $U K$ \\ e-mail:r.n.kiely@soton.ac.uk
}

\begin{abstract}
:
In communicative English language teaching classrooms, one of the main issues discussed is the teaching of forms. Research shows that Focus on Form (FoF) practice which focuses on building students' communicative ability is effective and desirable in helping students acquire their second language. This is unlike Focus on Forms (FoFs) practice which emphasises building students grammatical accuracy. However, many of the studies on FoF practices are designed within a controlled environment with pre-determined categories, which is different from an actual classroom setting. This study is conducted in actual communicative English language teaching classrooms to investigate teachers' FoF practices. Data were gathered from 15 non-participant classroom observations and interviews with three Malaysian ESL teachers. The data from the observations showed the teachers' tendency to employ isolated form-focused instructions (I-FFI) and reactive FoF practices in teaching grammar. However, the interviews revealed that the teachers focused more on helping students to master grammatical rules which conformed to the principle of FoFs practice. The contradicting findings suggest a complexity of teachers' actual practices which is not highlighted by many of the research studies in this area.
\end{abstract}

Keywords: teaching of grammar, communicative language teaching, focus on form, focus on forms 


\section{Introduction}

One of the main issues in communicative language teaching (CLT) is the treatment on grammar in the classrooms (Valeo \& Spada, 2016; Ellis, 2008; Spada, 2007). Ellis, Basturkmen \& Loewen's (2002) discuss 'focus-on-form' (FoF) which refers to "... the treatment of linguistic form in the context of performing a communicative task" (p. 1). In their discussion, FoF takes place when the need to highlight some linguistic features - grammar, lexical, phonological - arises during a communicative focused activities. In other words, FoF happens when students' ability to participate in communicative activities is hampered by the difficulty in understanding or using some linguistic forms. An FoF practice stresses the communicative purposes of learning a language. This is different from a 'Focus on formS' (FoFs) practice which stresses students' ability to produce grammatically correct language without any regards to students' communicative ability (Long \& Robinson, 1998). As the nature of a language is for communication, an FoF practice tends to be regarded as desirable and research on the effects of FoF practices has been abundance (Ellis, 2016; Spada et.al, 2014; Kartchava \& Ammar, 2014; Hernandez, 2011; Park, 2010). Most of the research was conducted in a controlled environment where the FoF practice was properly designed during some pre-determined categories to measure its effectiveness. However, teachers in the classrooms do not always work within a controlled environment where they purposely develop a method and test its effectiveness. Teachers' actual classroom practice involves a myriad of activities and interactions without specific focus on measuring the effectiveness of certain techniques or methods. According to Ellis et.al (2002), research on teachers' “ ... actual methodological procedures ..." in conducting FoF instructions is scarce (p.419). Since it has been demonstrated in a number of research studies that FoF is effective in teaching language forms, the purpose of this research study is to investigate teachers' actual practice in CLT classrooms - without any predetermined categories - during episodes on grammar. The intention is to explore the extent to which their practices conform to the principles of FoF practice. One issue that we focused on was determining the communicative nature of the practices because Willis (1990) posits that some communicative activities may only act as a vehicle for practicing accuracy. If this is the case, the teachers' practice is an FoFs rather than an FoF practice. The results of this study offer some insights into the actual dynamic of classroom interactions during episodes where grammar was focused on. Even though Ellis, et.al's (2002) term of 'form' refers to all aspects of linguistic form - phonological, phonological, lexical and grammatical - this article will focus only on the grammatical aspects of form.

\section{Literature Review}

\subsection{Theoretical background on focus on form instructions}

Language teaching and learning practices used to be distinguished between 'usage' and 'use' (Widdowson, 1978). 'Usage' is defined as “... that aspect of performance which makes evident the extent to which the language user demonstrates his knowledge of linguistic rules" (p. 3). In contrast, 'use' refers to one's ability to demonstrate his or her knowledge of using a language for effective communications. 
The distinction between 'usage' and 'use' seems to suggest that in language learning, students either learn to be structurally accurate or be communicatively fluent.

'Usage' and 'use' correspond with Long and Robinson's (1998) 'Focus on formS' (FoFs) and 'focus on meaning'. Similar to 'usage', FoFs stresses the learning and mastery of linguistic items such as grammar rules, phoneme, words and stress patterns. 'Focus on meaning' on the other hand, emphasizes the learning of languages "... by experiencing them as a medium for communication" (Long \& Robinson, 1998: p.18). In addition to FoFs and 'focus on meaning', Long \& Robinson (1998) propose another approach to language learning that is 'focus on form' (FoF) described as follows;

Although there are degrees of attention, and although attention to forms and attention to meaning are not always mutually exclusive, during an otherwise meaning-focused classroom lesson, focus on form often consists of an occasional shift of attention to linguistic code features - by the teacher and/or one or more students - triggered by perceived problems with comprehension or production (p.23).

Based on the description, it may be deduced that FoF combines the good of both 'usage'/FoFs as well as 'use'/Focus on meaning practices. FoF stresses the importance of learning to use the language for meaningful communicative purposes. This, however, is done without denying the role a structural knowledge of language plays in ensuring effective communication.

FoF may be conducted in two ways - planned FoF and incidental FoF (Ellis et.al, 2002). Using the terms 'proactive FoF' and 'reactive FoF', Doughty and Williams (1998), describe that 'proactive FoF', “... would entail selecting in advance an aspect of the target to focus on ..." (p.198). A reactive FoF on the other hand, does not involve selecting a linguistic item in advance but rather, reacting to a problem involving linguistic features which occurs while the focus of teaching and learning is on building communicative abilities.

The descriptions on the two types of FoF suggest that in planned or proactive FoF, teachers would decide the linguistic items they want students to engage with and purposely integrate these items in the communicative activities they plan for their students. This practice, even though similar to FoFs activities in some respects, is different in that, its focus is primarily meaning and teachers do not inform students the specific language items being emphasised on (Ellis et.al, 2002). The incidental or reactive FoF on the other hand, takes place only when the students or teachers choose to divert their attention from the communicative tasks at hand to some grammatical or lexical problems they encounter (Ellis et.al, 2002). This means that, for reactive FoF, both teachers and students may have the autonomy to decide on the linguistic items to focus on during classroom activities.

In relation to FoF is what Ellis (2001) and Spada (1997) term as "form-focused instruction" (FFI). According to Ellis (2001), FFI is “... any planned or incidental instructional activity that is intended to induce language learners to pay attention to 
linguistic forms" (pp.1-2). Spada (1997) defines FFI as “... any pedagogical effort to which is used to draw the learners' attention to language form either implicitly or explicitly" (p.73).

Using the term isolated and integrated FFI, Spada (1997) claims that isolated FFI is different from proactive $\mathrm{FoF}$ as teachers do not relate the linguistic forms in focus to any communicative or meaning related tasks during teaching. This means that, during isolated FFI, teachers may shift students' attention from the communicative task and focus entirely on developing students' linguistic forms accuracy. In other words, within a communicative activity, there might be a period of time when the entire focus is diverted towards, for example, a grammar item. This is in contrast to proactive FoF where attention to forms must occur within the context of a communicative task. However, Spada (1997) stresses that isolated FFI, even when it is devoid from any communicative traits, must be treated as an addition to the communicative practice. Therefore, isolated FFI must also occur within a communicative framework. Even when teachers' focus their attention on grammar, the purpose of learning the grammatical item is to enhance students' communicative ability. This is totally different from the FoFs practice where the focus is wholly on linguistic forms. The practice of integrated FFI however, is very similar to the practice of incidental and reactive FOF (Ellis et.a;, 2002; Doughty \& Williams, 1998).

The definition and practice of Spada's isolated FFI (henceforth I-FFI) pose some issues. The main issue lies in determining the communicative nature of an I-FFI practice that separates it from an FoFs practice. Spada's (1997) definition of I-FFI states that the teaching of forms can be isolated from any communicative activities but must be seen as a part of a communicative goal. In an actual classroom practice, however, determining the goal - whether it is communicative or not - is an uphill task. For example, in a class, students may be asked to write a letter advising a friend, which is communicative in nature. During the process, the teacher may shift the attention from the writing task to one specific grammar item to be used in the letter, which conforms to the practice of I-FFI. However, if the focus of the teacher's evaluation is on students' grammatical accuracy, the purpose of this task is not communicative. Therefore, teachers' action of focusing on a specific grammar item in preparation for the letter writing, cannot be seen as an I-FFI but rather, an FoFs practice. In a research study specifically designed to measure the effectiveness of an FoF practice, this kind of complexity may not be found as all variables will be carefully selected and controlled.

\subsection{Empirical research on focus on form instructions}

FoF has been widely discussed and researched on (van de Guchte et. al., 2016; Shintani, 2013; Spada \& Lightbown, 2008; Poole, 2005; Loewen, 2005; Sheen, 2003 \& Ellis, 2002). Even though FoF instructions suggest that attention to linguistic forms should occur within communicative related activities, Spada and Lightbown's (2008) study on FFI discovered that both isolated and integrated FFI were beneficial to students with different forms-related problems. Both types of instructions helped students to overcome their linguistic related problems depending on several factors 
such as the language feature to be learned, learners' characteristics and learning conditions. Unlike an FoF practice in which forms are dealt with only within the spectrum of communicative activities, this study suggested that deliberately planned activities on forms devoid of any communicative values were necessary even when the main focus of the lesson was communication. In other words, some teacherstudent interactions in a communicative classroom may not always need to be focusing on developing abilities to communicate.

On the same note with Spada and Lightbown's (2008) study, Wong and BarreaMarlys (2012) ascertained that some teachers believed in the importance of explicit form-focused instructions especially in the teaching of grammar. Based on the results of the interviews and observations, teachers' practices in the classrooms were the manifestations of their beliefs and experience. There were ample evidences of explicit grammar teaching in the participants' communicative English lessons. Even though this study was conducted in actual classroom settings, the purpose of the study was to compare teachers' beliefs and actual practices - not evaluating teachers' practices during explicit form-focused instruction episodes. Therefore, the results of this study do not fill the void mentioned by Ellis et al (2002) regarding the lack of research on teachers' actual practice of FoF in actual classrooms interactions.

In another study by Valeo and Spada (2016), teachers and learners were found to prefer integrated FFI over I-FFI for the teaching and learning of grammar. Using questionnaires, the researchers explored the teachers and learners' views on the values of integrated and isolated FFI in two contexts, ESL in Canada and EFL in Brazil. The results of this study highlights the tendency to favour integrated FFI over I-FFI but it does not reveal whether or not the practice in the classrooms is actually in line with the principles of integrated FFI.

The studies on FoF practice show that it is effective for the teaching of forms for communication. However they do not highlight how the practice is determined as FoF (especially I-FFI) and not FoFs. Two studies by Consolo (2006) and PeledElhanan and Blum-Kulka (2006) revealed the tendency for teachers to focus more on building students' grammatical accuracy rather than fluency in supposedly communicative classrooms. In other words, these studies suggested that communicative activities in the participants' classrooms were utilised to train students to produce accurate forms of language. The findings of these studies are in line with Willis's (1990) argument that in many communicative language classrooms, there is an inclination for teachers to emphasise the students' ability to produce accurate forms of language. This happens even when the activities are created for communicative purposes and interactional exchanges. Hence, the activities may not be truly 'communicative' but simply vehicles for the practice of forms. In such cases, the implementation is an FoFs practice, rather than an FoF practice.

The complication in determining whether or not a communicative activity is truly communicative adds to the need for investigating actual classroom interactions in order to evaluate the nature of teachers' FoF practice. Previous research has proven that FoF practice is effective in harnessing students' acquisition of linguistic items, 
which in turn helps them to communicate better. As such, teachers should be encouraged to employ FoF practice in their classrooms. The purpose of this study is therefore to explore the complexity of analyzing teachers' actual practice in communicative classrooms where FoF interactions should take place. According to Nassaji, instructions play a vital role in language teaching and learning, thus, understanding them is of paramount importance.

\section{Research Methodology}

\subsection{Context and participants}

This study was conducted in Malaysian English as a second language (ESL) classrooms. In Malaysia, English is taught using a communicative language syllabus. The syllabus document specifies the main aim of English language teaching and learning which is to enable students to use the language for communicative purposes. This is to be achieved by focusing on the four main skills - listening, speaking, reading and writing. (Curriculum Specification, 2003). Linguistic items such as grammar, vocabulary and phonology are to be integrated with the four skills. The supposedly communicative nature of English language lessons provides the merit of conducting the investigation on the practice of FoF in Malaysian ESL classrooms.

Based on the observations conducted, it can be summarized that a Malaysian ESL classroom was normally divided into four main stages - introduction, development, communicative practice and conclusion. A class started with a 5-minute introduction during which the teacher introduced the topic of the lesson. This was then followed by a development stage. Here, the teacher drew students' attention to the task for the lesson, revolving around the four skills such as a reading or a writing task. The teacher provided details of what the students were expected to do - i.e. answer reading comprehension questions or write an essay. This was also the part where attention to forms took place. The teacher engaged with the students in introducing and explaining any linguistic forms to be integrated within the reading or the writing task. I-FFI or proactive FoF interactions were likely to be observed here. This stage normally lasted for about 15 to 20 minutes. The lesson then moved to the communicative practice stage where students were to complete their task. Verbal interactions between the teacher and the students were very limited at this point as the students were working either individually, in pairs or in groups. The teacher silently monitored the students by walking around the class from one table to the other. This was the time when reactive FoF interactions were most likely to occur as the teacher occasionally reminded the students to check their use of linguistic forms. There was also the possibility of the students asking forms-related questions while doing their task. The duration of this stage depended on the length of the lesson. For a 40-minute lesson, the teacher allocated about 15-20 minutes and it was very common for the students to bring the task home if they did not manage to complete it within the stipulated time. For an 80-minute lesson, the teacher allocated about 40 to 45 minutes for the students to complete and submit their task. Finally, a class ended with a conclusion during which the teacher summarised the lesson. Students in Malaysian schools learn English for 200 minutes every week. These 200 minutes 
are divided into two 80-minute classes and one 40-minute class. It should be noted that even though the task in communicative language classrooms should cover all the four skills - reading, writing, listening and speaking - during the observations, we observed that the teachers focused only on reading and writing.

The participants of this study were three English language teachers with different years of experience. The teachers' profiles are as follows:

Teachers' Profile

\begin{tabular}{|l|l|}
\hline Teacher $1(\mathrm{~T} 1)$ & Female -12 years teaching experience. \\
\hline Teacher 2 (T2) & Female -14 years teaching experience. \\
\hline Teacher 3 (T3) & Male -10 years teaching experience. \\
\hline
\end{tabular}

\subsection{Data collection and analysis procedures}

Data for this study were collected through classroom observations and interviews with the teachers. Each teacher was observed for two weeks with the total of 15 lessons (6 classes for T1, 5 classes for T2 and 4 classes for T3).

Classroom observations were video recorded. The teachers themselves selected the classes we could observe and we did not object to any of their decisions in the efforts to ease their discomfort. According to Cohen et.al (2000), observations provide the opportunity for us to understand the actual nature of a programme. In the context of this research study, the observations exhibited teachers' practices in actual classroom settings when dealing with FoF instructions. The observation commenced from the moment the teachers entered the class and ended when they left the classroom. During the observation, we took the role of non-participant observers (Richard, 2003; Punch, 1998). The recorded videos were then transcribed. Based on the transcriptions, we were able to segment each 15 lesson into four different stages mentioned earlier. For the purpose of this article, we present a descriptive analysis of the data gathered from the development and communicative practice stages where FoF practices were evident.

In addition to the classroom observations, interviews were conducted with the teachers to further understand their practice in the classrooms. Bogden and Biklen (1998) assert that, “... interview is used to gather descriptive data in the subjects' own words so that the researcher can develop insights on how subjects interpret some piece of the world" (p.94). The foci of the interviews were mainly on 1) determining the teachers' focus when evaluating the task given to the students during each class and 2) their rationale of some decisions they made during classroom interactions. The interview data were important to further verify the nature of teachers' practice when dealing with forms during communicative activities. An audio-recorded interview was conducted with the teachers after each classroom observation (15 interviews in total). The interviews lasted between 15 to 30 minutes each. The recorded interviews were transcribed and we present the data in relation to the evidence from the classroom observations. 


\section{Findings and Discussion}

The analysis on the fifteen lessons observed showed that altogether there were fifteen instances of supposedly FoF episodes. These came in the forms of:

1) pre-planned activities (I-FFI) - four instances,

2) reminders from the teachers about the correct grammar forms to be used in writing or reading tasks(reactive FoF/incidental FFI) - ten instances,

3) a form-related question from a student (reactive FoF/incidental FFI) - one instance.

The pre-planned activities for grammar were developed to teach students the following grammatical items:

1) articles 'a' and 'the' (Teacher 1)

2) modals 'should' and 'ought to' (Teacher 2)

3) sentence connectors (Teacher 2)

4) 'be' verbs (Teacher 3)

\subsection{Isolated form-focused instructions}

The example of how an FoF episode occurred in the classrooms came from T1's class and this example is typical with T2's and T3's classes. In this 40-minute lesson, T1 wanted the students to write a paragraph describing a person they admired most. At the development stage, T1 first explained to the students about the task. She asked the students to think of a person they admired and wrote about the qualities of the person that made him or her admirable. She then continued as per the following excerpt:

\section{Classroom Excerpt 1: Teacher 1}

\begin{tabular}{|c|c|}
\hline TURNS & CLASSROOM INTERACTIONS \\
\hline $\mathrm{T}$ & $\begin{array}{l}\text { The teacher then goes to the blackboard and writes ' } a \text { ', 'an' and 'the'. } \\
\text { 'A', 'an' and 'the' (pointing to the three words she wrote on the board). } \\
\text { Do you remember this? We did some exercises on these a few weeks ago? }\end{array}$ \\
\hline Ss & Yes (in unison) \\
\hline $\mathrm{T}$ & $\begin{array}{l}\text { Okay, these are 'articles'. So we have 'a', 'an' and 'the'. } \\
\text { Alright, we use 'a' when noun is singular. } \\
\text { For example, okay, look how many pens I have in my hand? }\end{array}$ \\
\hline Ss & Ss: One \\
\hline $\mathrm{T}$ & $\begin{array}{l}\text { Yes, one. So 'a pen'. One pen. A pen. } \\
\text { What about 'an'? }\end{array}$ \\
\hline $\begin{array}{c}\text { Ss } \\
\text { (Jamie) }\end{array}$ & With a e i o u, teacher. \\
\hline $\mathrm{T}$ & $\begin{array}{l}\text { Yes, good, if the nouns start with vowels, then we use 'an' not 'a'. } \\
\text { What about honest? (writes 'honest' on the board) } \\
\text { An honest person or a honest person? }\end{array}$ \\
\hline
\end{tabular}




\begin{tabular}{|c|l|}
\hline $\begin{array}{c}\text { Ss } \\
\text { (Emily) }\end{array}$ & An honest teacher. \\
\hline $\mathrm{T}$ & Very good, Emily. You still remember. \\
& Okay, 'the'? \\
\hline Ss (Julie) & Specific. \\
\hline $\mathrm{T}$ & $\begin{array}{l}\text { Yes, when the noun is specific. } \\
\text { Okay. Obviously you do remember articles. Very good. } \\
\text { Now, when you write your paragraph about this person, I want you to underline all the } \\
\text { articles you use. Underline all of them. Do you understand? }\end{array}$ \\
\hline Ss & Yes (unison) \\
\hline
\end{tabular}

In the above excerpt, T1 discussed with her students the use of 'articles'. She first wrote the 'articles - a, an and the' on the blackboard before she asked about her students' familiarity with 'articles'. She then explained that ' $a$ ' is used with singular nouns. T1 further explained how 'a' was to be used by providing an example (One pen. A pen). The discussion on the use of 'articles' continued with T1 explaining the use of 'an' (nouns start with vowel) and 'the' (noun is specific).

The above interaction demonstrated how $\mathrm{T} 1$ cast aside the communicative task she wanted her students to do and shifted her attention to developing students' awareness of the English 'articles'. It can be observed from the excerpt that during this interaction the communicative value was not present as T1 focused entirely on forms. Even though T1 decided in advance the linguistic forms she wanted to expose to her students, her practice did not conform to Ellis et.al's (2002) and Doughty \& Williams' (1998) planned/proactive FoF. This is because T1 highlighted and informed the students about the 'articles' which is not how proactive FoF should be carried out. In a proactive FoF practice, students should not be made aware of any specific linguistic forms in focus. Instead, the teacher must manipulate his or her interaction with the students so that the need to use the specific linguistic forms for communication comes naturally.

The fact that $\mathrm{T} 1$ stepped aside from the communicative activity of writing about a person the students admired and focused entirely on a grammatical form made her practice more relevant to Spada's (1997) I-FFI. Unlike proactive FoF, the principle of I-FFI says that it is useful for the teacher to bring students' attention to forms even when they are doing a communicative activity. In this particular interaction, T1 did not make any connection between the communicative task she asked her students to do with the three 'articles'. The attention was returned back to the writing task only after T1 was satisfied that her students "remembered" the 'articles'.

Another example of an FoF episode was from T2's class. Similar to T1's, this was also a 40-minute lesson. This particular class was a continuation from a writing lesson conducted the day before. The students were asked to write sentences describing the advantages and the disadvantages of the internet in two separate columns. In this particular class, T2 started by discussing briefly what they did yesterday (introduction stage). At the beginning of the development stage, she told 
the students that they would turn those sentences into a complete essay. The class continued as per the following excerpt:

\section{Classroom Excerpt 2: Teacher 2}

\begin{tabular}{|c|c|}
\hline TURNS & CLASSROOM INTERACTIONS \\
\hline $\mathrm{T}$ & $\begin{array}{l}\text { Before you start writing, you remember right, I told you before, when you write you } \\
\text { need to make your ideas ... flow ... yes, flow. So how do you make your ideas flow? } \\
\text { Many ways, but one is by using sentence connectors. Do you know sentence } \\
\text { connectors }\end{array}$ \\
\hline $\begin{array}{c}\text { Ss } \\
\text { (Andy) }\end{array}$ & And? \\
\hline $\mathrm{T}$ & What did you say Andy? \\
\hline $\begin{array}{c}\text { Ss } \\
\text { (Andy) }\end{array}$ & And, sentence connector. \\
\hline $\mathrm{T}$ & $\begin{array}{l}\text { Yes, very good, Andy. And is a sentence connector. } \\
\text { Writes 'and' on the blackboard. } \\
\text { Any other sentence connectors? }\end{array}$ \\
\hline $\begin{array}{c}\text { Ss } \\
\text { (Lisa) }\end{array}$ & But, teacher. \\
\hline $\mathrm{T}$ & $\begin{array}{l}\text { Yes, but. Very good Lisa, right? Lisa. } \\
\text { Writes 'but' on the blackboard' } \\
\text { Very good. Anything else? }\end{array}$ \\
\hline Ss (Janet) & Or \\
\hline $\mathrm{T}$ & $\begin{array}{l}\text { Yes, or. } \\
\text { Writes 'or' on the blackboard. } \\
\text { Now, does anyone know when to use 'and' and 'but' and 'or'? } \\
\text { Okay, you use 'and' when you have two same ideas. For example, Lisa is pretty. Janet } \\
\text { is pretty. So how do you write this? }\end{array}$ \\
\hline $\begin{array}{c}\text { Ss } \\
\text { (Lisa) }\end{array}$ & Lisa and Janet is pretty... eh eh... Lisa and Janet are pretty (Laughs) \\
\hline $\mathrm{T}$ & $\begin{array}{l}\text { Very good Lisa. Lisa and Janet are pretty. Same idea. } \\
\text { What about but? Hmmm ... Didie, you are quiet today. Want to tell me. When do you } \\
\text { use but? }\end{array}$ \\
\hline $\begin{array}{c}\text { Ss } \\
\text { (Didie) }\end{array}$ & Lisa is pretty but Janet is ugly (Laughs) \\
\hline Ss & Ss: Laugh \\
\hline $\mathrm{T}:$ & $\begin{array}{l}\text { Janet, you are not ugly, okay (Laughs). } \\
\text { You are correct Didie. You use but when you have two contradicting ideas. Do you } \\
\text { know what is contradicting? Contradicting means different. So pretty and ugly are } \\
\text { contradicting right? So you use 'but'. } \\
\text { What about 'or' }\end{array}$ \\
\hline
\end{tabular}




\begin{tabular}{|c|l|}
\hline $\begin{array}{c}\text { Ss } \\
\text { (Jake) }\end{array}$ & No? No one knows? Come on ... I'm sure you know. \\
\hline $\mathrm{T}$ & What is that Jake? \\
\hline $\begin{array}{c}\text { Ss } \\
\text { (Jake) }\end{array}$ & Or ... this one or that one teacher. I don't know how to tell (Laughs) \\
\hline $\mathrm{T}$ & $\begin{array}{l}\text { I know Jake. You use 'or' when there is a choice. When we are not sure which one. } \\
\text { Who will get the highest mark for English? Sara or Amber? } \\
\end{array}$ \\
$\begin{array}{l}\text { Okay, remember the writing piece I gave you yesterday? Now, I want you to rewrite } \\
\text { that but this time, you need to connect the ideas using 'and', 'but' and 'or'. }\end{array}$ \\
\hline
\end{tabular}

The above excerpt demonstrated how T2 explained and discussed with her students the use of sentence connectors. She started by informing the students about sentence connectors followed by providing examples of sentence connectors. During this discussion, it can be observed that $\mathrm{T} 2$ did not make any reference to the topic of the writing task - the internet. The focus of the discussion was solely on the sentence connectors which suggests an inclination towards Spada's (1997) I-FFI. Even though the sentence connectors discussed were grammatical items selected in advance, the above interaction cannot be classified as planned/proactive FoF (Ellis et.al, 2002 ; Doughty \& Williams, 1998). This is because the interaction was devoid of any communicative value.

The two excerpts presented are typical examples of how the pre-planned activities for grammar teaching and learning were conducted in the classrooms observed. All of the teachers showed the tendency towards I-FFI practice as the grammatical items in focus were explained to the students without any connection to the communicative tasks.

\subsection{Reactive Focus on Form}

Apart from the I-FFI episodes, the classroom observations revealed some episodes of reactive FoF. One example is from T1's class. Upon completing the episode of IFFI in Classroom Excerpt 1, T1 then asked her students to start writing their paragraph (communicative practice stage). As stated earlier, verbal interactions were very limited. The following excerpt showed one of the verbal interactions that took place during this stage in T1's class.

\section{Classroom Excerpt 3: T1}

\begin{tabular}{|c|l|}
\hline TURNS & \multicolumn{1}{|c|}{ CLASSROOM INTERACTIONS } \\
\hline T & $\begin{array}{l}\text { Plural for child is childs? } \\
\text { (The teacher said this after walking around the class checking her students' work) }\end{array}$ \\
\hline Ss & Ss : (Silent) \\
\hline T & $\begin{array}{l}\text { What is the plural form for child class? } \\
\text { Children, not child. Remember we learn before, child - children, goose ...? }\end{array}$ \\
\hline Ss & Ss : Geese \\
\hline T & Very good \\
\hline
\end{tabular}


The above interaction took place ten minutes into the communicative practice stage. T1 moved from one table to the other and she suddenly asked the question about the plural form for the word 'child'. This, we believe, is an example of a reactive FoF/incidental FFI practice (Doughty \& Williams, 1998; Spada, 1997). During a communicative activity, a reactive $\mathrm{FoF}$ instruction takes place in response to students' difficulty in using a specific linguistic item. In this particular lesson, there was no prior discussion on plural forms for nouns and the students were writing their paragraphs when this question was posted. T1 verified in the interview conducted with her after the lesson that the grammar form was not selected in advance. She chose to draw students' attention to the correct use of plural nouns as she noticed a number of students made similar errors in their writing. She said,

I noticed many of them wrote childs, rather than children. Well, this is quite common errors for the students ... adding 's' to all plural nouns ... you know ... sometimes I ignored ... I mean I only correct the errors when I marked their work ... their writing ... but I also tell them ... to the whole class their errors while they are doing their work ... just to make them aware. This is especially when I notice many of them make the same errors.

The other two teachers also claimed that at the communicative practice stage, they would alert their students of some grammatical errors they made especially when the majority of them made the same errors.

The above excerpt shows an example of a teacher-initiated reactive FoF. The following excerpt shows an evidence of a student-initiated reactive FoF. This particular example is taken from one of T3's classes. The main task for this 80 minute class was to write a paragraph describing students' pets. During the development stage, T3 explained about writing the paragraph and provided fifteen words that he wanted his students to use in their paragraphs. The words were mainly adjectives that could be used to describe a pet. Once this stage was completed, T3 then asked his students to start writing. The following excerpt took place 15-minutes into the communicative practice stage.

\section{Classroom Excerpt 3: T3}

\begin{tabular}{|c|l|}
\hline TURNS & \multicolumn{1}{c|}{ CLASSROOM INTERACTIONS } \\
\hline $\begin{array}{c}\text { Ss } \\
(\mathrm{Bob})\end{array}$ & $\begin{array}{l}\text { Teacher, Its food, apostrophe no apostrophe teacher? } \\
\text { (The students at this point are writing a paragraph about their pets) }\end{array}$ \\
\hline $\mathrm{T}$ & What? \\
\hline $\begin{array}{c}\text { Ss } \\
(\mathrm{Bob})\end{array}$ & Its food, I T S no apostrophe or I T apostrophe S. I confused. \\
\hline $\mathrm{T}$ & It with apostrophe (Writes it's on the blackboard) is a short form for “it is". \\
& So what do you think? Its with no apostrophe or it's with apostrophe? \\
\hline $\begin{array}{c}\text { Ss } \\
(\mathrm{Bob})\end{array}$ & $\begin{array}{l}\text { With apostrophe, eh eh... its, no apostrophe (Laughs). I T S food. } \\
\text { Thank you Sir. }\end{array}$ \\
\hline
\end{tabular}


The interaction took place when a student $(\mathrm{Bob})$ raised a question related to the use of an apostrophe to show possession. The teacher then engaged in a discussion where he briefly explained the difference between "its" and "it's". This is an example of how a student may also be the initiator of a reactive FoF practice in a communicative classroom (Doughty \& Williams, 1998). The student, Bob encountered a problem in determining the right form to use in describing his pet and decided to raise the issue to his teacher. The focus on this particular grammar item was not pre-planned by $\mathrm{T} 3$ and it was also not a problem that he highlighted to his students. In the interview conducted after this lesson, T3, claimed that,

... students normally don't ask questions about grammar. I think because ... hmmmm ... they don't know they are making mistakes ... errors ... (laughs). Vocabulary, yes. When they write, they ask ... Sir how to say this and that in English ... more of getting the right words for writing. Grammar ... very rare ... When they ask questions about grammar, I tell them what is the right form. I don't explain ... hmmmm ... long explanation ... just a short one because the focus is on writing ...

T3's explanation indicated that student-initiated reactive FoF episode on grammar was a rare episode. We could verify that in the fifteen observations (eleven evidences of reactive FoF), this particular example was the only evidence of studentinitiated reactive FoF on grammar. The other ten reactive FoF episodes were all teacher-initiated.

\subsection{Focus on FormS}

Based on the classroom observations on the three teachers, we recorded four I-FFI episodes and eleven reactive FoF episodes. This, we believe is an indication that in actual classroom practices, FoF instructions are utilised to teach grammar.

Even though the analysis on the classroom interactions reveal that the tasks given to the students were communicative in nature, the interview with $\mathrm{T} 1$ after her lesson presented in Classroom Excerpts 1 and 3, suggests a different idea. T1 said,

I want to make sure that they ... I mean the students ... can use articles correctly. So when I mark their essays ... their paragraphs ... they got them right. I don't ... you know ... of course I will look at the descriptions of the people they ... wrote $\ldots$ but $\ldots$ yes $\ldots$ more importantly ... I look at the articles. We're not supposed to teach grammar in isolation ... you know. So this is how I do it. Reading or writing ... then I include some grammatical items. When I check ... the focus is ... on grammar ... accuracy. I can't really evaluate their ... skills ... I mean communication skills. I hope that ... eventually ... with this kind of activities ... you know ... writing activities plus some grammar ... eventually ... they 
become better. When? I'm not sure (laugh). With time, they will get better.

The above response was given by T1 when asked about her focus in evaluating her students' written work. The other two teachers (T2 and T3) also gave similar answers when asked about their focus of evaluation. T2 stated,

Yes ... my lesson normally focused on reading or writing ... when I marked ... I mean when I checked their work ... hmmm ... yes ... grammar plays a role. I mean ...let say writing ... the one you observed yesterday ... write a letter and they had to use modals ... ought to and should ... So when I marked ... I of course focus on these two ... Did the students use these modals correctly ... at the same time ... I also look at the overall ... you know ... overall impression ... of course the content ... but contents are given to the students so they will get it correct. The grammar will differentiate the good students and the weak ones ... I circle or underline all the grammar errors ... not only the two modals ... but other errors as well ... so those with less marks on their writing will ... you know ... naturally get higher marks ... so ... hmmm ... I do stress the grammar bit ... because this would determine their marks ...

Similar answer was given by T3 who claimed,

Well ... evaluation ... mark the writing ... grammar ... (laughs). I focus on grammar, yes. You see ... in a writing class for example, we discuss with the students what to write ... you know ... so everyone will write about the same thing ... almost ... the difference is grammar ... so writing is for the students to practice their grammar. We can teach grammar but if they don't use it, then we don't know whether they understand or not. So their writing is when we ... I mean ... check their grammar ...

All of the teachers were in echo when describing the evaluation of their students' work. Based on the responses, it can be suggested that the teachers' goal for their lessons was not developing their students' communicative ability but rather harnessing students' grammatical accuracy. Their practices were similar to the arguments brought forward by Consolo (2006), Peled-Elhanan \& Blum-Kulka (2006) and Willis (1990) that some communicative activities may actually be used as a vehicle for students to practice their knowledge of grammar. As such, T1's practice in Classroom Excerpt 1 for example, that was earlier analysed as an evidence of I-FFI, may actually be a practice of FoFs. In addition, the evidence on reactive FoF practice presented in Classrooms Excerpt 3 is simply a further proof that $\mathrm{T} 1$ put a lot of emphases on her students' accurate use of grammar. 


\section{Conclusion}

The findings of this study provide some insights into the practice of teaching grammatical forms in actual communicative classrooms. The data suggest that attention to grammar comes in the forms of I-FFI as well as reactive FoF/incidental FFI. All three teachers involved in this study displayed similar practices. Their lessons revolved around one communicative task - usually reading or writing - and specific grammatical items were selected to be used in the tasks. We believe that the teachers' practices in the classrooms were influenced by the Malaysian English language syllabus that specifies integration of grammar within communicative activities focusing on the four language skills (Curriculum Specification, 2003).

The revelations by the three teachers suggest that if the focus of our analysis is on the classroom interactions, their grammar teaching can be categorized as an I-FFI practice. However, their admissions about the focus of the task evaluation show an inclination towards an FoFs practice. The two contrasting practices that could be attached to the same classroom interactions display the complexity of analyzing teachers' interactions in actual classroom settings. Broszkiewicz (2011) posits that even though FoF practice - in her study, she uses the term 'focused communication tasks' - is effective, designing and implementing it in the classrooms may not be easy for the teachers. This is because designing an activity with an FoF focus requires experience and knowledge.

This research study was conducted to investigate teachers' practice of FoF instructions in actual communicative classroom settings. The study discovered evidences of I-FFI and reactive FoF/incidental FFI practices. However, there were also indications that point towards FoFs practices especially when evaluation of students' tasks is focused on.

The argument we present here shows the complex dynamic of actual communicative language classroom practices. Unlike the data from the controlled environment where research studies on FoF instructions are normally conducted, the data presented in this study show that different factors need to be considered before a teacher's interaction can be regarded as an FoF practice. This study was based on the practices of only three teachers. The data were also obtained from a small number of classroom observations which may not be typical of the context. Therefore, the interpretation of the findings has taken these limitations into consideration.

\section{References}

Bogdan, R. C., \& Biklen, S.R. (1998). Qualitative research for education. An introduction to theory and methods. Boston: Allyn and Bacon.

Broszkiewicz, A. (2011). The effect of focused communication tasks on instructed acquisition of English pas counterfactual conditionals. Studies in Second Language Learning and Teaching, 1(3), 335-363.

Cohen, L., Manion, L. et al. (2000). Research methods in education. London: Routledge. 
Consolo, D. A. (2006). Classroom oral interaction in foreign language lesson and implications for teacher development. Linguagem \& Ensino,9(2), 23-35.

Curriculum Specifications (2003). Curriculum Development Center, Ministry of Education. Kuala Lumpur.

Doughty, C. \& Williams, J. (1998). Pedagogical choices in focus on form. In C. Doughty \& J. Williams (Eds), Focus on form in classroom second language acquisition (pp197-261). Cambridge: Cambridge University Press.

Ellis, R. (2001). Introduction: Investigating form-focused instruction. Language Learning, 51, Issue Supplements1, 1-46.

Ellis, R., Basturkmen, H. \& Loewen, S. (2002). Doing focus-on-form. Systems,30, 419-432.

Ellis, R. (2002). Does form-focused instruction affect the acquisition of implicit knowledge? SSLA, 24, 46-58.

Ellis, R. (2008). The study of second language acquisition. Oxford: Oxford University Press.

Ellis, R. (2016). Focus on form: A critical review. Language Teaching Research, 20(3), 405-428.

Hernandez, T. (2011). Re-examining the role of explicit instruction and input flood on the acquisition of Spanish discourse markers. Language Teaching Reseacrh, 15(2), 159-182.

Katchava, E., \& Ammar, A. (2014). The noticeability and effectiveness of corrective feedback in relation to target types. Language Teaching Research,18(4), 428452.

Loewen, S. (2005). Incidental focus on form and second language acquisition. SSLA, 27, 23-37

Long, M. H., \& Robinson, P. (1998). Focus on form: Theory, research, and practice. In C. Doughty and J. Williams (Eds.), Focus on form in classroom second language acquisition (pp15-41). Cambridge: Cambridge University Press.

Nassaji, H. (2017). Language instruction and language acquisition: A complex interplay. Language Teaching Research, 21(5), 543-545.

Park, S. (2010). The influence of pre-task instructions and pre-task planning on focus on form during Korean EFL task-based interaction. Language Teaching Research,14(1), 9-26.

Peled-Elhanan, N., \& Blum-Kulka, S. (2006). Dialogue in the Israeli classroom: Types of teacher-student talk. Language and education,20(2), 121-137.

Poole, A. (2005). Focus on form instruction: Foundations, applications and criticisms. The Reading Matrix, 5(1), 34-47.

Punch, K. (1998). Introduction to social research: Quantitative and qualitative approaches. London: Sage.

Richards, K. (2003). Qualitative inquiry in TESOL. Basingstoke: Palgrave MacMillan.

Sheen, R. (2003). Focus on form - A myth in the making? English Language Teaching Journal, 57(3), 225-233. 
Shintani, N. (2013). The effect of Focus on Form and Focus on Forms instruction on the acquisition of productive knowledge of L2 vocabulary by young beginning-level learners. TESOL Quarterly,47(1), 36-62.

Spada, N. (1997). Form-focused instruction and second language acquisition: A review of classroom and laboratory research. Language Teaching,30, 73-87.

Spada, N. (2007). Communicative language teaching: Current status and future propects. In J. Cummins \& C. Davison (Eds.), International handbook of English language teaching (pp271-288). USA: Springer US.

Spada, N., \& Lightbown, P.M. (2008). Form-focused instruction: Isolated or integrated? TESOL Quarterly, 42(2), 181-207.

Spada, N. et.al. (2014). Isolated and integrated form-focused instructions: Effects on different types of L2 knowledge. Language Teaching Research,18(4), 453473.

van de Guchte, M., Braaksma, M., Rijlaarsdam, G., \& Bimmel, P. (2016). Focus on form through task repetition in TBLT. Language Teaching Research, 20(3), 300-320.

Valeo, A. \& Spada, N. (2016). Is there a better time to Focus on Form? Teacher and learner views. TESOL Quarterly, 50(2), 314-339.

Widdowson, H. G. (1978). Teaching language as communication. Oxford: Oxford University Press.

Willis, D. (1990). The lexical syllabus. London: Collins Cobuild.

Wong, C.C.Y., \& Barrea-Marlys, M. (2012). The role of grammar in communicative language teaching: An exploration of second language teachers' perceptions and classroom practices. Electronic Journal of Foreign Language Teaching, 9(1), 61-75. 